\title{
Catalytic reduction of NO by methane using a Pt/C/polybenzimidazole/Pt/C fuel cell
}

\author{
Petrushina, Irina; Cleemann, Lars Nilausen; Refshauge, Rasmus; Bjerrum, Niels; Bandur, Viktor
}

Published in:

Journal of The Electrochemical Society

Link to article, DOI:

$10.1149 / 1.2722532$

Publication date:

2007

Document Version

Publisher's PDF, also known as Version of record

Link back to DTU Orbit

Citation (APA):

Petrushina, I., Cleemann, L. N., Refshauge, R., Bjerrum, N., \& Bandur, V. (2007). Catalytic reduction of NO by methane using a Pt/C/polybenzimidazole/Pt/C fuel cell. Journal of The Electrochemical Society, 154(6), E84E90. https://doi.org/10.1149/1.2722532

\section{General rights}

Copyright and moral rights for the publications made accessible in the public portal are retained by the authors and/or other copyright owners and it is a condition of accessing publications that users recognise and abide by the legal requirements associated with these rights.

- Users may download and print one copy of any publication from the public portal for the purpose of private study or research.

- You may not further distribute the material or use it for any profit-making activity or commercial gain

- You may freely distribute the URL identifying the publication in the public portal 


\title{
Catalytic Reduction of NO by Methane Using a $\mathrm{Pt} / \mathrm{C} /$ polybenzimidazole/Pt/C Fuel Cell
}

\author{
I. M. Petrushina, ${ }^{*, z}$ L. N. Cleemann, R. Refshauge, N. J. Bjerrum, ${ }^{*}$ and \\ V. A. Bandur
}

Materials Science Group, Department of Chemistry, Technical University of Denmark, DK-2800 Lyngby, Denmark

\begin{abstract}
The catalytic NO reduction by methane was studied using a $\left(\mathrm{NO}, \mathrm{CH}_{4}, \mathrm{Ar}\right), \mathrm{Pt} \mid$ polybenzimidazole $(\mathrm{PBI})-\mathrm{H}_{3} \mathrm{PO}_{4} \mid \mathrm{Pt},\left(\mathrm{H}_{2}, \mathrm{Ar}\right)$ fuel cell at 135 and $165^{\circ} \mathrm{C}$. It has been found that, without any reducing agent (like $\mathrm{CH}_{4}$ ), $\mathrm{NO}$ can be electrochemically reduced in the $(\mathrm{NO}, \mathrm{Ar}), \mathrm{Pt} / \mathrm{C}\left|\mathrm{PBI}-\mathrm{H}_{3} \mathrm{PO}_{4}\right| \mathrm{Pt} / \mathrm{C},\left(\mathrm{H}_{2}, \mathrm{Ar}\right)$ fuel cell with participation of $\mathrm{H}^{+}$or electrochemically produced hydrogen. When added, methane partially suppresses the electrochemical reduction of NO. Methane outlet concentration monitoring has shown the $\mathrm{CH}_{4}$ participation in the chemical catalytic reduction, i.e., methane co-adsorption with $\mathrm{NO}$ inhibited the electrochemical NO reduction and introduced a dominant chemical path of the NO reduction. The products of the NO reduction with methane were $\mathrm{N}_{2}, \mathrm{C}_{2} \mathrm{H}_{4}$, and water. The catalytic NO reduction by methane was promoted when the catalyst was negatively polarized $(-0.2 \mathrm{~V})$. Repeated negative polarization of the catalyst increased the NO conversion. Maximum NO conversion was $48 \%$. This effect was explained as a result of the reaction of the electrochemically produced hydrogen.

(c) 2007 The Electrochemical Society. [DOI: 10.1149/1.2722532] All rights reserved.
\end{abstract}

Manuscript submitted July 7, 2006; revised manuscript received February 27, 2007. Available electronically April 18, 2007.

The catalytic reduction of $\mathrm{N}_{x} \mathrm{O}_{y}$ plays a very important role in pollution control. Although there is already a developed industrial process for selective catalytic reduction of $\mathrm{N}_{x} \mathrm{O}_{y}$ with $\mathrm{NH}_{3}$, the use of hydrocarbons has attracted much attention, because their cost is much lower than that of $\mathrm{NH}_{3}$. Particular methane would be convenient because the development of natural gas-powered vehicles will require the development of more active catalysts to remove $\mathrm{N}_{x} \mathrm{O}_{y}$ from the exhaust. ${ }^{1-3}$

The present work is a continuation of our research in the fields of electrochemical promotion ${ }^{4-6}$ and fuel cells, first the phosphoric acid fuel cells ${ }^{7}$ and in the last ten years the polybenzimidazole (PBI)phosphoric acid fuel cells. ${ }^{8}$ The latter have a combination of advantages obtained from polymeric electrolyte fuel cells and phosphoric acid fuel cells, especially the ability to work at temperatures up to $200^{\circ} \mathrm{C}$, i.e., elimination of the problem of $\mathrm{CO}$ poisoning of the $\mathrm{Pt}$ catalyst.

The fact that a catalyst is often a system, which consists of an electronic and an ionic conductor, makes it possible to use electrochemical techniques to study the mechanism and kinetics of catalytic reactions. Application of galvanic cells with solid electrolytes for the study of catalytic phenomena was suggested by Wagner. ${ }^{9}$ Pancharatham et al. ${ }^{10}$ discovered that the rate of a catalytic reduction of $\mathrm{NO}$ on a $\mathrm{Pt} / \mathrm{ScO}_{2}$-stabilized $\mathrm{ZrO}_{2}$ catalyst can be significantly enhanced by an electrolytic removal of oxygen.

It was found by Vayenas et al. ${ }^{11}$ that rate and selectivity of a catalytic reaction can be remarkably (up to hundreds of times) and reversibly changed by electrochemical polarization of an electronic conductive catalyst on an ionic conductive support. This phenomenon was named the nonfaradaic electrochemical modification of catalytic activity (NEMCA) or electrochemical promotion ${ }^{12}$ (EP) effect.

The EP effect has been demonstrated for more then 50 catalytic reactions and can be described by the following parameters: ${ }^{12}$

The rate enhancement ratio

$$
\rho=r / r_{o}
$$

and the enhancement factor

$$
\Lambda=\left(r-r_{o}\right) /(I / n F)
$$

where $r$ is the catalytic reaction rate at current $I, r_{o}$ is the opencircuit catalytic reaction rate, $n$ is the valence of the current-carrier ions in the solid electrolyte, and $F$ is Faraday's constant. In all

\footnotetext{
* Electrochemical Society Active Member.

z E-mail: impetr@kemi.dtu.dk
}

studied cases of the electrochemical promotion $|\Lambda| \gg 1$, and that was the reason why this effect has been called nonfaradaic.

In our previous papers ${ }^{5,6}$ we have defined two types of electrochemical promotion, based on the assumption that the catalytic activity was a result of a change in the Fermi level of the catalyst during electrochemical polarization of the catalyst. ${ }^{12-18}$ The Fermi level can be changed simply by charging of the electric double layer at the interface catalyst-support (change of the outer, Volta potential) without electrochemical reaction. Therefore, this kind of electrochemical promotion was called charge-induced (CI) EP. We registered the CI promotion in the case of EP of catalytic reaction on a liquid catalyst ${ }^{4}$ and in the case of $\mathrm{EP}$ of catalytic NO reduction with hydrogen in the $\left(\mathrm{NO}, \mathrm{H}_{2}, \mathrm{Ar}\right), \mathrm{Pt} / \mathrm{C}\left|\mathrm{PBI}-\mathrm{H}_{3} \mathrm{PO}_{4}\right| \mathrm{Pt} / \mathrm{C},\left(\mathrm{H}_{2}, \mathrm{Ar}\right)$ fuel cell in the case of high hydrogen partial pressure (effect of a positive polarization) ${ }^{6}$

Another type of EP is in the case when the Fermi level of the catalyst is changed by changing of the chemical potential, i.e., through an electrochemical reaction. This case was named the electrochemical production of promoters (EPP). ${ }^{6}$ The difference between EPP and electrocatalysis is that in the latter the products of the catalytic reaction $(\Lambda \leqslant 1)$ are electrochemically produced and in the former the promoters of the catalytic reaction are electrochemically produced $(\Lambda \gg 1)$. The classic example of this EPP case is an electrochemical production of sodium from the $\mathrm{Na}^{+}$ions in $\beta^{\prime \prime}-\mathrm{Al}_{2} \mathrm{O}_{3}$ catalyst support. ${ }^{19-21}$ Electrochemically produced oxygen $^{12}$ and hydrogen ${ }^{5,6}$ can also be considered as promoters.

In the studies of an electrochemical promotion of the catalytic $\mathrm{NO}$ reduction by propene at $375^{\circ} \mathrm{C}$, Na was pumped to the surface of the catalyst using electrochemical reduction of $\mathrm{Na}^{+}$ions from $\mathrm{Na}$ $\beta^{\prime \prime}$-alumina support. ${ }^{19-21}$ This supply of $\mathrm{Na}$ was seen to greatly enhance (2-3 times for $\mathrm{N}_{2}$ production) the reduction of $\mathrm{NO}$ on the $\mathrm{Pt}$ (or Rh) catalyst. Simultaneously, the selectivity of production of $\mathrm{N}_{2}$ against $\mathrm{N}_{2} \mathrm{O}$ was seen to increase. It has been shown by Lambert et al. ${ }^{19-21}$ that the effect of electrochemical promotion is equivalent to the effect seen from depositing $\mathrm{Na}$ chemically on the catalyst surface. It means that the effect had an EPP nature.

Yentekakis et al. also studied an effect of sodium (chemical promotion) on the $\mathrm{Pd} / \mathrm{Y}$-stabilized zirconia (YSZ)-catalyzed reduction of NO by methane at $347-497^{\circ} \mathrm{C} .{ }^{22}$ It has been found that unlike the reduction of NO by propene, ${ }^{19-21}$ the reduction of NO by methane is strongly poisoned by sodium. ${ }^{22}$

It was shown in our study on electrochemical promotion of the catalytic oxidation of methane by oxygen in the $\left(\mathrm{CH}_{4}, \mathrm{O}_{2}, \mathrm{Ar}\right)$, $\mathrm{Pt}|\mathrm{PBI}| \mathrm{Pt},\left(\mathrm{H}_{2}, \mathrm{Ar}\right)$ fuel cell at 100 and $135^{\circ} \mathrm{C}^{5}$ that use of the proton-conducting electrolyte creates a new oxidative coupling of the methane $(\mathrm{OCM})$ route (parallel to the methane oxidation to $\mathrm{CO}_{2}$ ) 
to acetylene. It was also shown that the $\mathrm{C}_{2}$ production and $\mathrm{C}_{2}$ selectivity can be promoted by a pumping of protons to the catalyst/ electrolyte interface, i.e., at the negative catalyst polarization with the maximum $V_{\mathrm{WR}}$ [voltage between the working and the reference (or counter) electrode of the fuel cell] $=-0.15 \mathrm{~V}\left(3.8 \% \mathrm{C}_{2} \mathrm{H}_{2}\right.$ maximum yield and $r_{\max }=4.2$ ). Moreover, the maximum promotion effect takes place in the same potential range as the electrochemical reduction reaction, which is assumed to be the electrochemical reduction of protons to hydrogen, and that therefore the $\mathrm{C}_{2} \mathrm{H}_{2}$ production is promoted by the electrochemically produced hydrogen. The fact that $\Lambda \gg 1$ means that the promotion effect is not electrocatalytic but EPP in nature. It can be assumed that the presence of $\mathrm{Pt}-\mathrm{H}_{\text {ads }}$ sites improves the $\mathrm{CH}_{4}$ and $\mathrm{O}_{2}$ cochemisorption conditions.

In our previous study on the electrochemical promotion of the catalytic $\mathrm{NO}$ reduction by hydrogen in the $\left(\mathrm{NO}, \mathrm{H}_{2}, \mathrm{Ar}\right), \mathrm{Pt}|\mathrm{PBI}| \mathrm{Pt}$, $\left(\mathrm{H}_{2}, \mathrm{Ar}\right)$ fuel cell at $135^{\circ} \mathrm{C}$, ${ }^{6}$ we have found that $\mathrm{NO}$ was reduced to $\mathrm{N}_{2}$. It has been shown that electrochemical promotion is possible for this reaction. However, the nature of the EP effect depended strongly on the partial pressure of the reactants. At low partial pressures, there was a clear EPP effect. In this case the reaction was electrochemically promoted at negative polarization. The maximum promotion effect $\left(9.3 \% \mathrm{NO}\right.$ conversion) was at $V_{\mathrm{WR}}=-0.15 \mathrm{~V}$, i.e., at the same voltage as in the case of the methane conversion. The catalytic rate enhancement ratio at this maximum was 4.65. There was no NO conversion at $-0.3 \mathrm{~V} \leqslant V_{\mathrm{WR}} \leqslant 0.1 \mathrm{~V}$. These data gave more proof to the assumption about the role of the electrochemically produced hydrogen as a promoter of the studied catalytic reactions.

As was previously mentioned, at high partial pressures of the reactants, the EP effect took place at the positive polarization and had a CI nature. The electrochemical production of the extra adsorbed hydrogen probably had a poisoning effect on the catalytic NO reduction with hydrogen.

Electrochemical promotion of $\mathrm{NO}$ reduction by $\mathrm{C}_{3} \mathrm{H}_{6}$ (or $\mathrm{CO}$ ) was also found to take place when the catalyst support was an $\mathrm{O}^{2-}$ conductor, i.e., Rh (or Pd)/YSZ catalyst. For this kind of system, an increase in the $\mathrm{NO}$ reduction rate was obtained when $\mathrm{O}^{2-}$ was removed from (or in some cases added to) the catalytic surface. ${ }^{23-26}$

Recently the electrochemical NO reduction was studied on the $\mathrm{Pt}$ electrode of the $\left(\mathrm{NO}, \mathrm{O}_{2}\right), \mathrm{Pt}|\mathrm{Nafion}| \mathrm{Pt},\left(\mathrm{H}_{2} \mathrm{O}\right)^{27}\left(70^{\circ} \mathrm{C}\right)$ and $(\mathrm{NO}$, $\left.\mathrm{O}_{2}, \mathrm{Ar}\right), \mathrm{Pt} / \mathrm{C} \mid \mathrm{In}^{3+}$-doped $\mathrm{SnP}_{2} \mathrm{O}_{7} \mid \mathrm{Pt} / \mathrm{C}\left(\text { Air, } \mathrm{H}_{2} \mathrm{O}\right)^{28}\left(150-300^{\circ} \mathrm{C}\right)$ fuel cells. In these papers the fuel cell with proton-conducting electrolytes were shown as effective "electrochemical NO filters" even in the presence of oxygen. In both cases the reaction had an electrocatalytic nature with participation of $\mathrm{H}^{+}$from the electrolytes or electrochemically produced $\mathrm{H}$ atoms.

The aim of the present work was to study the catalytic reduction of $\mathrm{NO}$ by methane on a $\mathrm{Pt} / \mathrm{PBI}\left(\mathrm{H}_{3} \mathrm{PO}_{4}\right)$ catalyst at 135 and $165^{\circ} \mathrm{C}$ during the catalyst polarization. Taking into account the diversity of the mechanisms described above, one of our main aims was an investigation of the mechanism of the NO reduction by methane.

\section{Experimental}

The experimental setup is shown in Fig. 1. Carbon-supported Pt catalyst with Pt load around $0.5 \mathrm{mg} / \mathrm{cm}^{2}$ was used in the present investigation. ${ }^{29} \mathrm{~A}$ transmission electron microscopy (TEM) image of the $\mathrm{Pt} / \mathrm{C}$ catalyst is given in Fig. 2. The TEM images were obtained using a Philips 430 TEM microscope.

The electrolyte was polybenzimidazole (PBI)-doped with $\mathrm{H}_{3} \mathrm{PO}_{4}$. The techniques of preparing the $\mathrm{PBI}\left(\mathrm{H}_{3} \mathrm{PO}_{4}\right)$ membrane electrolyte and the $\mathrm{Pt} / \mathrm{C}$, $\mathrm{PBI}\left(\mathrm{H}_{3} \mathrm{PO}_{4}\right), \mathrm{Pt} / \mathrm{C}$ assembly (the working electrode area is $5 \mathrm{~cm}^{2}$ ) were developed in our group as well as by others. $^{30,31}$

The PBI used was poly 2,2'-m-(phenylene)-5,5'-bibenzimidazole, synthesized from 3, $3^{\prime}$-diaminobenzidine tetrahydrochloride (Aldrich) and isophthalic acid (Aldrich) by polymerization in polyphosphoric acid (PPA) at $170-200^{\circ} \mathrm{C}$, as described in Ref. 31. The membranes were doped by immersing them in $75 \%$ phosphoric acid solutions for at least a week at room temperature. This doping

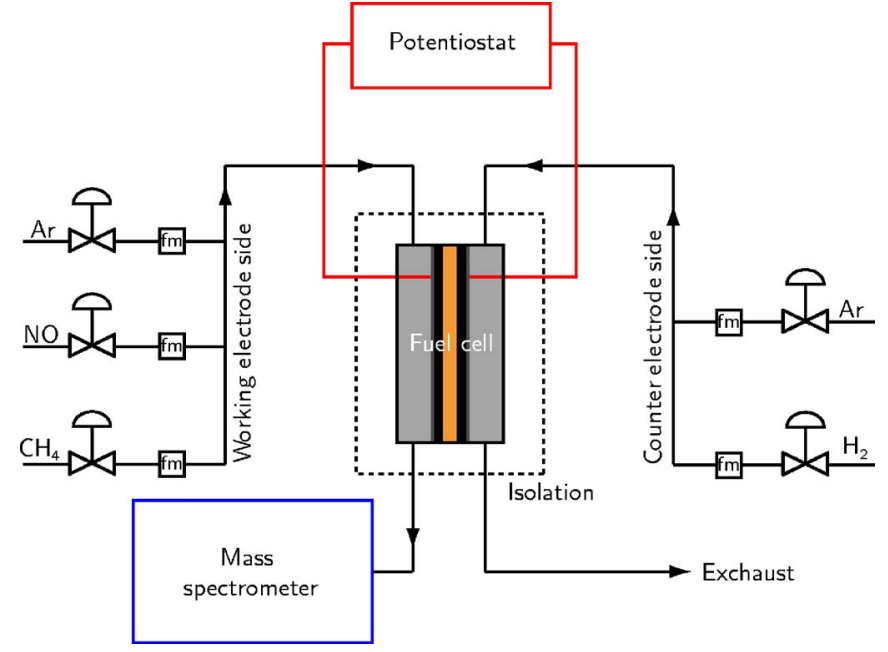

Figure 1. (Color online) Experimental setup.

procedure gives an acid-doping level of about $5.6 \mathrm{~mol} \mathrm{H}_{3} \mathrm{PO}_{4}$ per repeating unit of the polymer and a doped thickness of $80 \mu \mathrm{m}$. The conductivity of the membranes at $135^{\circ} \mathrm{C}$ was measured at $0.03 \mathrm{~S} \mathrm{~cm}^{-1}$.

Electrodes were prepared using a tape casting method and subsequently hot pressed to the PBI membrane to form a membrane electrode assembly (MEA). The complete procedure for electrode preparation is described in detail in Ref. 30.

Graphite plates with gas channels were used as holders and current collectors. Two aluminum end plates with attached heaters were used to clamp the graphite plates. The temperature was controlled by a homemade controller. Mass-flow meters (5850 S Brookssmart) and 0154 Brooks Instrument controllers were used to control the inlet gas composition. The outlet gas composition was measured by an online quadrupole mass spectrometer (QMS 421, Pfeiffer) with a secondary electron multiplier detector and a cross-beam ion source with a rhenium filament. The ionization voltage was $70 \mathrm{~V}$. The cata-

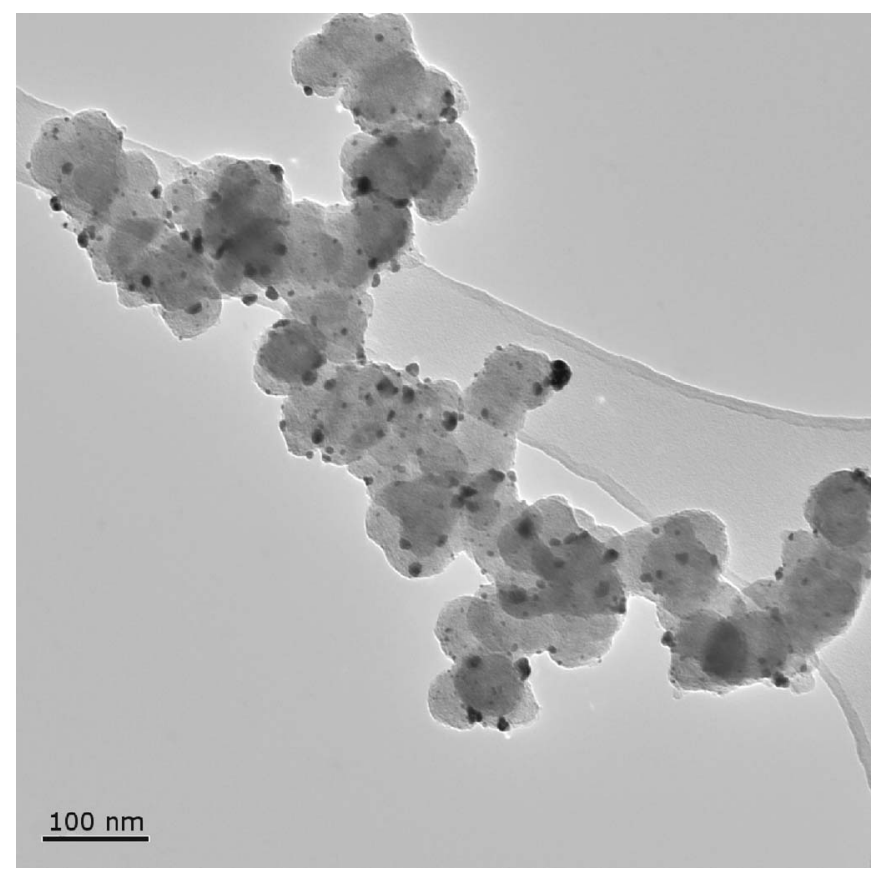

Figure 2. TEM image of the Pt/C catalyst; black spots are the Pt particles. 


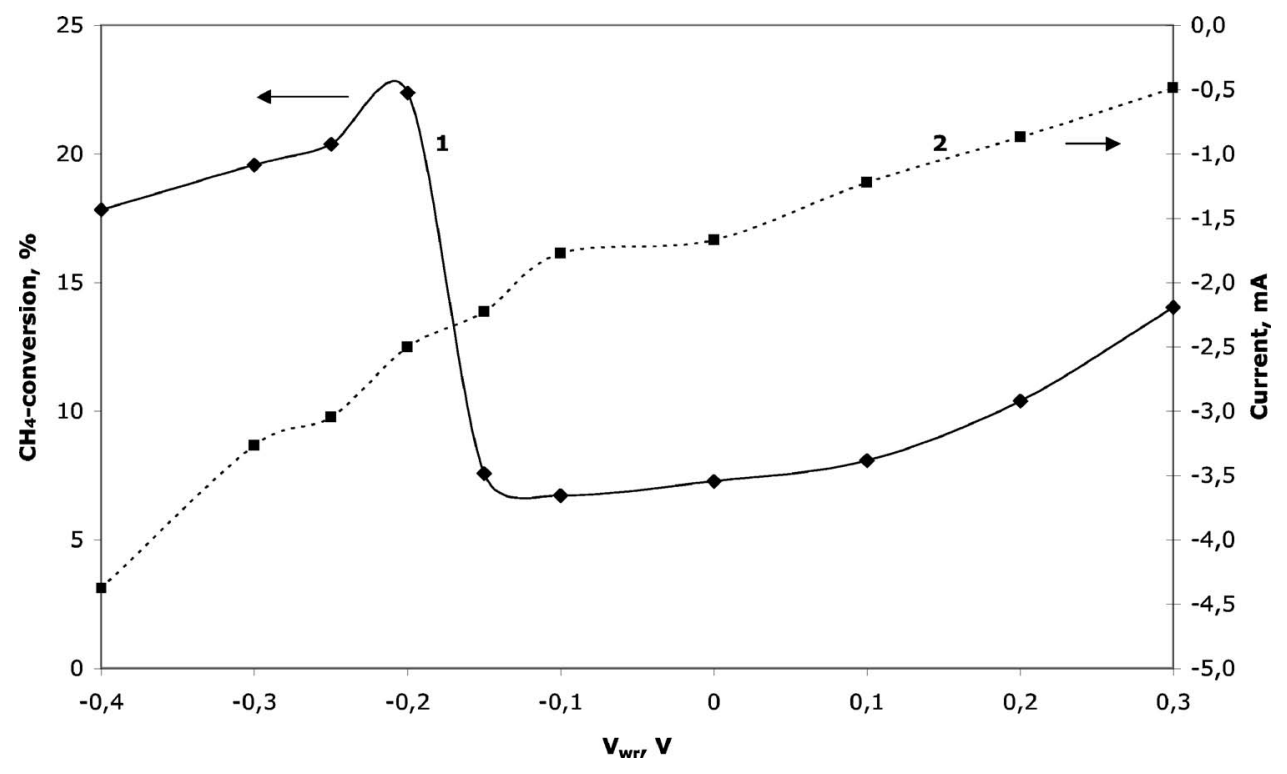

Figure 3. $\mathrm{CH}_{4}$ conversion vs $V_{\mathrm{WR}}$ obtained in the $\left(\mathrm{NO}, \mathrm{CH}_{4}, \mathrm{Ar}\right)$, $\mathrm{Pt}\left|\mathrm{PBI}-\mathrm{H}_{3} \mathrm{PO}_{4}\right| \mathrm{Pt},\left(\mathrm{H}_{2}, \mathrm{Ar}\right)$ fuel cell at $135^{\circ} \mathrm{C}$ and atmospheric pressure (curve 1). Steady-state voltammetric curve obtained in the same conditions (curve 2). This was the 1 st polarization run.

lytic reaction products were also identified with a gas chromatograph HP 6890 with the HP-MOLESIEVE column $(30 \mathrm{~m}$ $\times 0.32 \mathrm{~mm} \times 250 \mu \mathrm{m})$.

The mixture of $\mathrm{NO}$ and methane diluted by $\mathrm{Ar}\left(\mathrm{CH}_{4}, \mathrm{NO}\right.$, and $\mathrm{Ar}=17,17$, and $354 \mathrm{~mL} / \mathrm{min}$, respectively) was used as a working mixture at one electrode and hydrogen/argon mixture $\left(\mathrm{H}_{2}\right.$ and $\mathrm{Ar}$ were 17 and $371 \mathrm{~mL} / \mathrm{min}$, respectively) was used as a reference and a counter gas at the other electrode; the counter gas was humidified by bubbling it through ionized water. The temperature was 135 and $165^{\circ} \mathrm{C}$ and all experiments were done at atmospheric pressure.

Commercial gases $\mathrm{H}_{2}\left(>99.9 \%, \leqslant 10 \mathrm{ppm}\right.$ of $\mathrm{O}_{2}, \leqslant 15 \mathrm{ppm}$ of $\mathrm{H}_{2} \mathrm{O}$ ) (from Strandmøllen A/S), $\mathrm{Ar}\left(<40\right.$ ppm $\left.\mathrm{O}_{2}+\mathrm{H}_{2} \mathrm{O}\right), \mathrm{CH}_{4}$ $(\geqslant 99.5 \%)$, and $\mathrm{NO}(>99.9 \%)$ from AirLiquid-Alphagas were used.

An EG\&G Instrument (Princeton Applied Research) 283 potentiostat/galvanostat controlled by 352 SoftCorr III software and homemade cyclic voltammetry software was used in the electrochemical measurements. The measurements of the catalytic activity were performed at potentiostatic conditions. The catalytic activity at open-circuit voltage $(\mathrm{OCV})$ was measured after the yield of gas products had stabilized, i.e., under steady-state conditions. For each value of voltage the measurements were performed after stabilization of the yield of gas products and current $(0.5-1.0 \mathrm{~h})$, i.e., at steady-state conditions. Because of the relatively high conductivity of the membrane and the low currents observed, the maximum internal resistance (iR) drop is calculated to be $0.2 \mathrm{mV}$ (at $4 \mathrm{~mA}$ ). Therefore, no correction for iR losses were performed.

\section{Results and Discussion}

The gas chromatography analysis of the products of catalytic reduction of $\mathrm{NO}$ with methane were nitrogen, ethylene, and water. It therefore can be assumed that the following catalytic reaction takes place

$$
2 \mathrm{CH}_{4}+2 \mathrm{NO} \rightarrow \mathrm{C}_{2} \mathrm{H}_{4}+2 \mathrm{H}_{2} \mathrm{O}+\mathrm{N}_{2}
$$

This means that OCM takes place during the reduction of $\mathrm{NO}$ with methane in $\left(\mathrm{NO}, \mathrm{CH}_{4}, \mathrm{Ar}\right), \mathrm{Pt}|\mathrm{PBI}| \mathrm{Pt},\left(\mathrm{H}_{2}, \mathrm{Ar}\right)$ fuel cell at $135^{\circ} \mathrm{C}$. This result is not in agreement with the data obtained in the study of the same catalytic reaction on Pt-group metals where the methane oxidation to carbon dioxide took place. ${ }^{1-3,22}$ It should be taken into account, however, that the catalytic reduction of NO by methane on Pt-group catalysts was proved to have a LangmuirHinhelwood-type kinetics at $347-497^{\circ} \mathrm{C},{ }^{22}$ and with high probability this is valid at lower temperatures as well. ${ }^{1,2}$ This kinetics means competitive adsorption of $\mathrm{NO}$ and methane on the catalyst surface, with $\mathrm{NO}$ adsorption being much more pronounced than $\mathrm{CH}_{4}$ adsorp- tion. This also means that the reaction kinetics and mechanism are very sensitive to the $\mathrm{NO} / \mathrm{CH}_{4}$ ratio, oxygen presence, temperature, and, of course, the catalyst.

OCM was one of the two main mechanisms of the methane oxidation by oxygen in the PBI fuel cell at $135^{\circ} \mathrm{C} .5$ Ethylene was also the main OCM product if a solid oxide fuel cell (SOFC) with YSZ electrolyte was used. ${ }^{32-36}$ In this case methane and oxygen were separated by the electrolyte; $\mathrm{CH}_{4}$ passed over the positive electrode and $\mathrm{O}_{2}$ passed over the negative electrode. The oxygen was electrochemically reduced. The oxide ions were pumped to the positive electrode and oxidized again to oxygen. The methane was oxidized by this oxygen. The described mechanism was a classic electrocatalytic reaction. The reaction proceeded at $600-900^{\circ} \mathrm{C}$ and was studied at numerous catalysts. ${ }^{32-36}$

The results of the first polarization run of the $\left(\mathrm{NO}, \mathrm{CH}_{4}, \mathrm{Ar}\right)$, $\mathrm{Pt}|\mathrm{PBI}| \mathrm{Pt},\left(\mathrm{H}_{2}, \mathrm{Ar}\right)$ system at $135^{\circ} \mathrm{C}$ are given in Fig. 3. The $\mathrm{CH}_{4}$ conversion was calculated on the basis of mass spectral data, and the mass spectrometer was calibrated with flows containing a known composition of $\mathrm{CH}_{4}$.

There is a difference between most of the electrochemical systems used in EP experiments ${ }^{12}$ and the fuel cell used in the present paper. In the former case the membrane (solid electrolyte)/electrodes assembly is placed in a tightly closed cell with the working gas atmosphere in it and, therefore, the voltage between working and reference (or working and counter) electrodes is zero. In our case there are different gases at the working and the reference (counter) electrodes. Therefore, the OCV is not zero. In order to define the EP effect on the catalytic reaction, the working electrode should first be polarized to zero voltage vs the hydrogen reference (counter) electrode, i.e., $V_{\mathrm{WR}}=0$.

Before the first steady-state polarization the OCV of the cell was $0.372 \mathrm{~V}$. The methane conversion at the OCV was $20.4 \%$. If the NO oxidation takes place only by chemical reaction with methane, the NO conversion, according to the Reaction 3, was also $20.4 \%$.

It can be seen from Fig. 3 (curve 1) that the methane conversion significantly drops in the beginning when the catalyst is polarized negatively from OCV $(0.372 \mathrm{~V})$. It is also clear that there is a promotion effect which starts at $V_{\mathrm{WR}}=-0.1 \mathrm{~V}$ and has a maximum (22.4\% methane conversion, $\rho=3.1$ ) $V_{\mathrm{WR}}=-0.15$ (Fig. 3, curve 1). Comparison of curve $1\left(\mathrm{CH}_{4}\right.$ conversion) and curve 2 (steadystate voltammetric curve) in Fig. 3 shows that there are electroreduction processes both in the case of the methane conversion drop in the beginning of the polarization and in the case of the promotion of the catalytic reaction. The latter takes place in the same voltage area as the EP effect in our previous study on the methane catalytic 


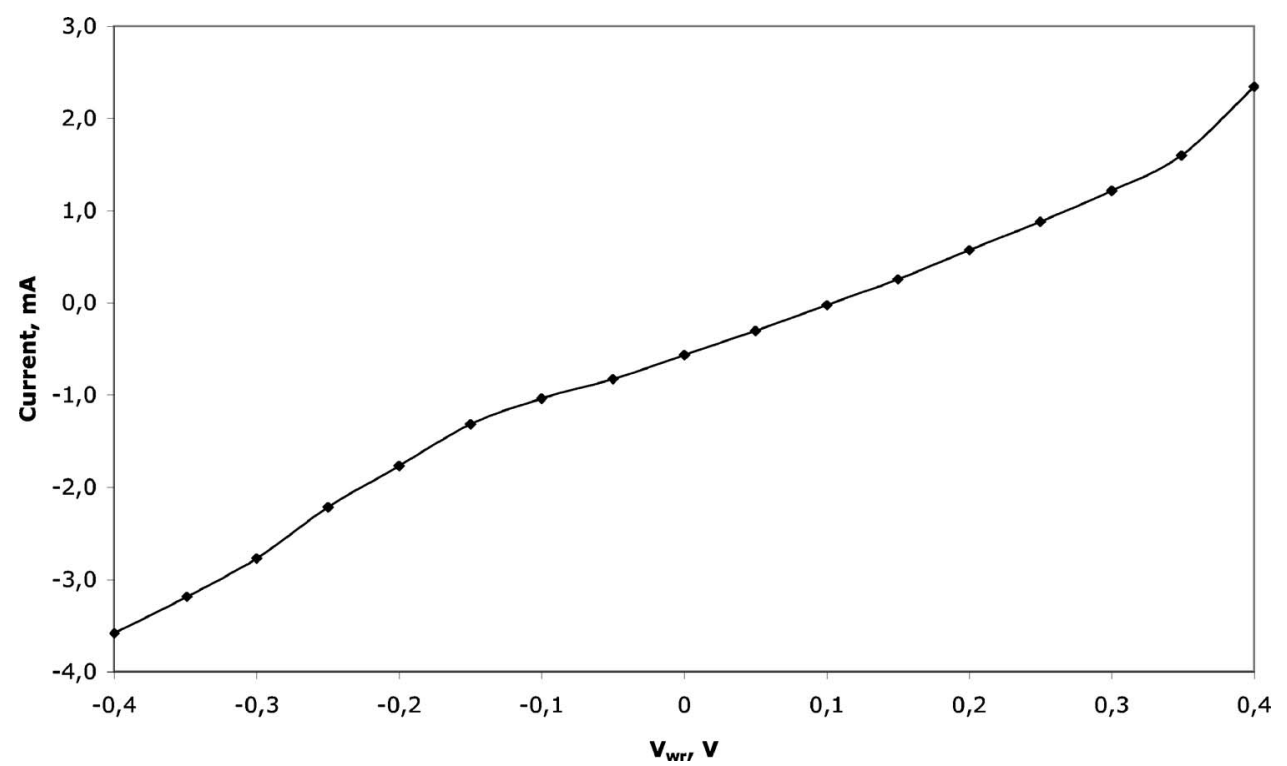

Figure 4. Steady-state voltammetric curve obtained in the $(\mathrm{Ar})$, $\mathrm{Pt}\left|\mathrm{PBI}-\mathrm{H}_{3} \mathrm{PO}_{4}\right| \mathrm{Pt},\left(\mathrm{H}_{2}, \mathrm{Ar}\right)$ fuel cell at $135^{\circ} \mathrm{C}$.

oxidation by oxygen ${ }^{5}$ and the NO reduction with hydrogen ${ }^{6}$ in the PBI fuel cell. It was assumed in our previous papers that these two reactions were promoted by electrochemically produced hydrogen. In the present study, additional electrochemical measurement was made to prove this assumption. In the present experiment only $\mathrm{Ar}$ gas was at the working electrode during its polarization. The results are presented in Fig. 4. It can be seen from Fig. 4 that there is an electroreduction reaction which starts at approximately $-0.15 \mathrm{~V}$, i.e., at the same voltage at which the promotion effect takes place in Ref. 5 and 6 and in Fig. 3. In pure Ar atmosphere the only possible electrochemical reaction is

$$
\mathrm{H}^{+}+\mathrm{e} \rightarrow \mathrm{H}
$$

The drop in the methane conversion at the start of the polarization, i.e., at positive potentials of the catalyst and the fact that the electroreduction reaction takes place at the same potentials (Fig. 3) lead to an assumption about direct electrochemical reduction of NO. In order to test this assumption, cyclic voltammetric measurement was made with $\mathrm{NO}+\mathrm{Ar}$ and $\mathrm{NO}+\mathrm{CH}_{4}+\mathrm{Ar}$ gas flows on the side of the working electrode. The results are given in Fig. 5. Comparison of curves 1 and 2 in Fig. 5, i.e., the results obtained in pure $\mathrm{Ar}$ and $\mathrm{NO}+\mathrm{Ar}$ atmospheres, shows that indeed the electrochemical reduction of NO starts at the potentials close to OCV (Fig. 5, curve 1 and 2). Addition of methane (Fig. 5, curve 3) suppresses the reduction current. This fact can be explained by the co-adsorption of $\mathrm{NO}$ and $\mathrm{CH}_{4}$ at the catalyst and chemical reduction of $\mathrm{NO}$ by methane.

The results obtained during the 1st, 2 nd, and 3rd polarization runs at $135^{\circ} \mathrm{C}$ are given in Fig. 6 . The 3 rd run is performed after the two polarization runs at $165^{\circ} \mathrm{C}$ (Fig. 7). It can be seen from Fig. 6 that for all runs there is a polarization effect which starts at $-0.15 \mathrm{~V}$

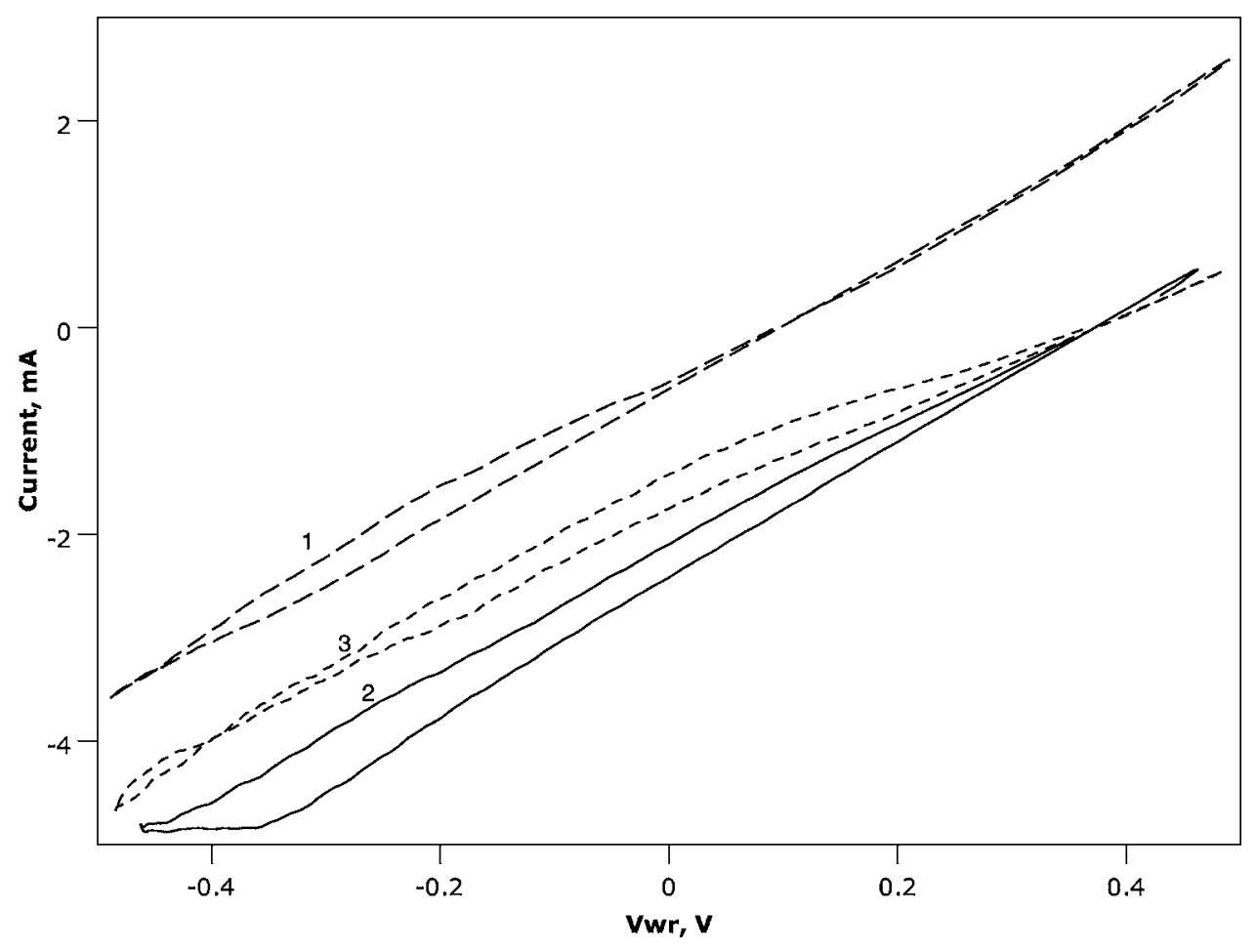

Figure 5. Cyclic voltammetric curves obtained (1) in the (Ar), $\mathrm{Pt}\left|\mathrm{PBI}-\mathrm{H}_{3} \mathrm{PO}_{4}\right| \mathrm{Pt}$, $\left(\mathrm{H}_{2}, \mathrm{Ar}\right)$ fuel cell at $135^{\circ} \mathrm{C}$, (2) in the ( $\mathrm{NO}, \mathrm{Ar}), \mathrm{Pt}\left|\mathrm{PBI}-\mathrm{H}_{3} \mathrm{PO}_{4}\right| \mathrm{Pt},\left(\mathrm{H}_{2}, \mathrm{Ar}\right)$ fuel cell at $135^{\circ} \mathrm{C}$, and (3) in the $\left(\mathrm{NO}, \mathrm{CH}_{4}, \mathrm{Ar}\right), \mathrm{Pt}\left|\mathrm{PBI}-\mathrm{H}_{3} \mathrm{PO}_{4}\right| \mathrm{Pt},\left(\mathrm{H}_{2}, \mathrm{Ar}\right)$ fuel cell at $135^{\circ} \mathrm{C}$. 


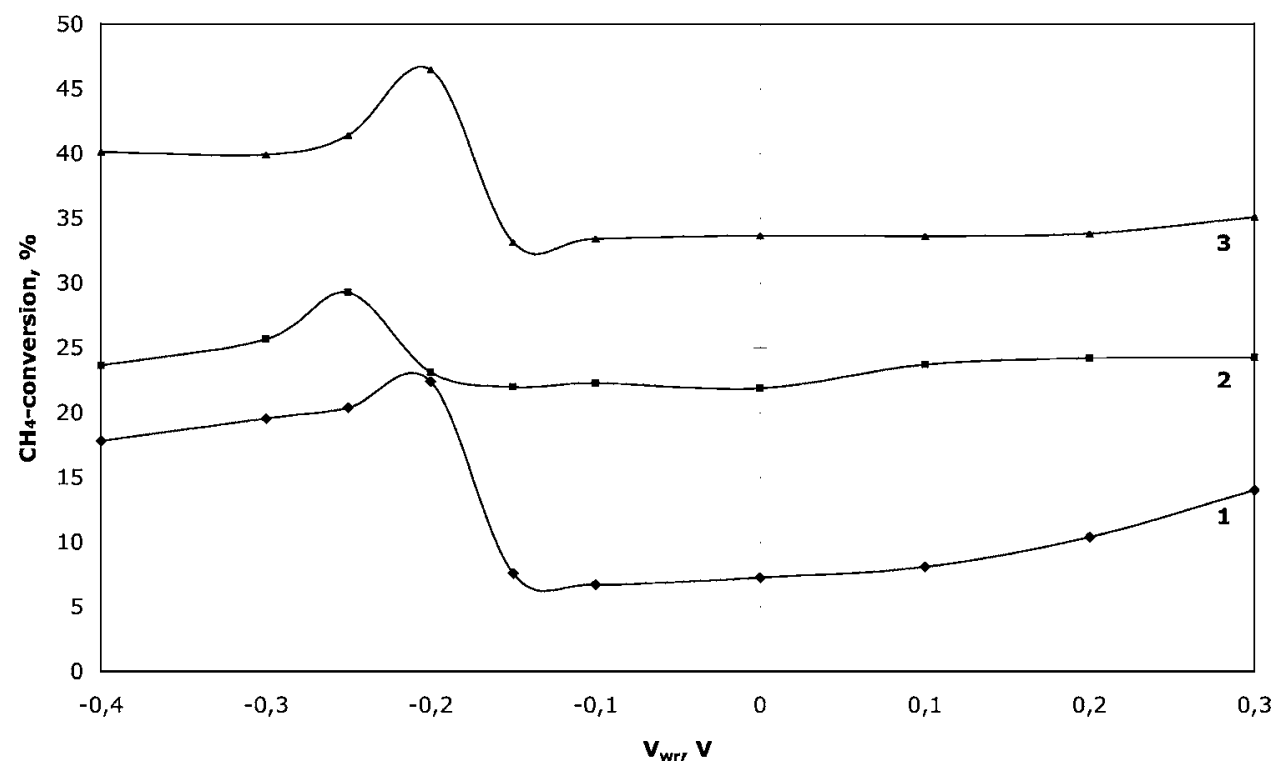

Figure 6. $\mathrm{CH}_{4}$ conversion vs $V_{\mathrm{WR}}$ obtained in the $\left(\mathrm{NO}, \mathrm{CH}_{4}, \mathrm{Ar}\right), \mathrm{Pt} \mid \mathrm{PBI}-$ $\mathrm{H}_{3} \mathrm{PO}_{4} \mid \mathrm{Pt},\left(\mathrm{H}_{2}, \mathrm{Ar}\right)$ fuel cell at $135^{\circ} \mathrm{C}$ during the 1 st (curve 1 ), 2 nd (curve 2 ), and 3 rd (curve 3 ) negative polarization runs. Curve 3 was obtained after the polarization run at $165^{\circ} \mathrm{C}$. and has a maximum at $-0.2 \mathrm{~V}$. However, it is evident that the polarization effect is irreversible; there is an increase in the catalyst activity and simultaneous decrease in the rate enhancement ratio, $\rho$, (from 3.1 at the 1st run to 1.3-1.4 at the 2 nd and 3rd runs) after each negative polarization run. The highest methane conversion value, i.e., $46.5 \%$, was obtained during the third polarization run at $V_{\mathrm{WR}}$ $=-0.2$ to $-0.25 \mathrm{~V}$. Taking into account the stoichiometry of Reaction 3 , there should be the same NO chemical conversion value. This result is remarkable because the NO conversion by methane obtained by other research groups is close to zero at temperatures $\leqslant 200^{\circ} \mathrm{C}$. ${ }^{1,2,22}$

Based on their knowledge about kinetics of NO reduction by methane, Yentekakis et al. ${ }^{22}$ explained why $\mathrm{Na}$, instead of being a promoter, poisons the catalyst. "Na inhibits the adsorption of $\mathrm{CH}_{4}$ by enhancing the adsorption of NO. The clean-off of $\mathrm{O}$ (a) by adsorbed hydrocarbonaceous species is thereby inhibited, leading to an overall loss of activity towards all products, principally due to poisoning by O(a)." Assuming the same kinetics of the NO reduction by methane in the studied fuel cell system, we can also explain the irreversible promotion effect of the negative polarization. The electrochemically produced hydrogen activates the catalyst by removal of the extra $\mathrm{O}(\mathrm{a})$, which is the result of different adsorption rates of $\mathrm{NO}$ and $\mathrm{CH}_{4}$.

Figure 7 presents the data obtained at $135^{\circ} \mathrm{C}$ (2nd run) and that at $165^{\circ} \mathrm{C}$. There is also an increase of the catalytic activity at the negative $V_{\mathrm{WR}}$ at $165^{\circ} \mathrm{C}$. The maximum activity (33\% of methane conversion) was obtained at $-0.15 \mathrm{~V}$, i.e., at more positive potential than at $135^{\circ} \mathrm{C}$. However, change in the maximum catalyst activity (29 and $33 \%$ methane conversion at 135 and $165^{\circ} \mathrm{C}$, respectively) with the temperature increase is not as significant as the increase of the activity during the successive runs at negative polarization at $135^{\circ} \mathrm{C}$ (Fig. 6). The rate enhancement ratio, $\rho$, changes from 1.3 at $135^{\circ} \mathrm{C}$ (Fig. 7a) to 1.5 at $165^{\circ} \mathrm{C}$ (Fig. 7b), i.e., also a small change. The NO electrochemical activity is much lower at 165 than at $135^{\circ} \mathrm{C}$ (compare the steady-state voltammetric curves in Fig. 7a and b). This can be explained by a more weak NO adsorption at higher temperatures. It can also affect the NO oxidation by methane. This assumption is in agreement with the data obtained during the 3rd polarization run at $135^{\circ} \mathrm{C}$ (Fig. 6, curve 3) after the run at $165^{\circ}$ (Fig. $7 b)$.

To calculate the amount of the electrochemically reduced NO, we assumed that the following electrochemical reaction takes place

$$
\mathrm{NO}+2 \mathrm{H}^{+}+2 \mathrm{e} \rightarrow \frac{1}{2} \mathrm{~N}_{2}+\mathrm{H}_{2} \mathrm{O}
$$

$100 \%$ faradaic efficiency was also assumed. The results obtained for the 3 rd run at $135^{\circ} \mathrm{C}$ are given in Fig. 8. Curve 1 in Fig. 8 shows the NO conversion resulting from Reaction 3 The dashed curve (curve 2) shows NO conversion with added electrochemically reduced NO. The electrochemical part was calculated on the basis of Reaction 3 and the currents obtained at different potentials. In the presence of methane, only $3.4 \%$ of NO was oxidized electrochemically.

\section{Conclusions}

The reduction of $\mathrm{NO}$ by methane was studied in $\left(\mathrm{NO}, \mathrm{CH}_{4}, \mathrm{Ar}\right)$, $\mathrm{Pt}\left|\mathrm{PBI}-\mathrm{H}_{3} \mathrm{PO}_{4}\right| \mathrm{Pt},\left(\mathrm{H}_{2}, \mathrm{Ar}\right)$ fuel cell at 135 and $165^{\circ} \mathrm{C}$. It has been shown that in this system NO can be reduced chemically by methane and electrochemically through Reaction 5 . In the presence of methane the NO reduction mainly proceeded chemically, i.e., by methane. The maximum faradaic part of NO conversion reached $3.4 \%$ of the net $\mathrm{NO}$ conversion.

The NO reduction was affected by negative polarization of the catalyst. A decrease of the $\mathrm{CH}_{4}$ conversion between the $\mathrm{OCV}$ and $V_{\mathrm{WR}}=0.1 \mathrm{~V}$ was observed. This fact was explained by the interference of the electrochemical NO reduction. Starting with $V_{\mathrm{WR}}=$ $-0.15 \mathrm{~V}$, there was an increase $(\rho=3.1$ for the first polarization run) of the methane conversion with maximum at $V_{\mathrm{WR}}=-0.2$ to $-0.25 \mathrm{~V}$. This promotion effect was irreversible; the methane conversion increased after each negative polarization run reaching the 3rd run maximum of $46.5 \%$ methane conversion at $135^{\circ} \mathrm{C}$. According to Reaction 3 stoichiometry, the NO conversion had the same value, and taking into account the Faradaic part, the maximum NO reduction was $48 \%$.

It has been shown that in the potential range of the promotion effect the electrochemical reduction of the electrolyte protons took place. The promotion effect was explained by the assumption that the electrochemically produced hydrogen activates the catalyst by removal of the extra $\mathrm{O}(\mathrm{a})$, which is the result of different adsorption rates of $\mathrm{NO}$ and $\mathrm{CH}_{4}$.

There was no significant effect of temperature increase (from 135 to $165^{\circ} \mathrm{C}$ ) on the catalyst activity in the NO reduction by methane. There was, however, a decrease in the electrochemical reduction of NO.

\section{Acknowledgment}

This investigation has been supported by project no. 21-03-0483 of the Danish Research Agency. 

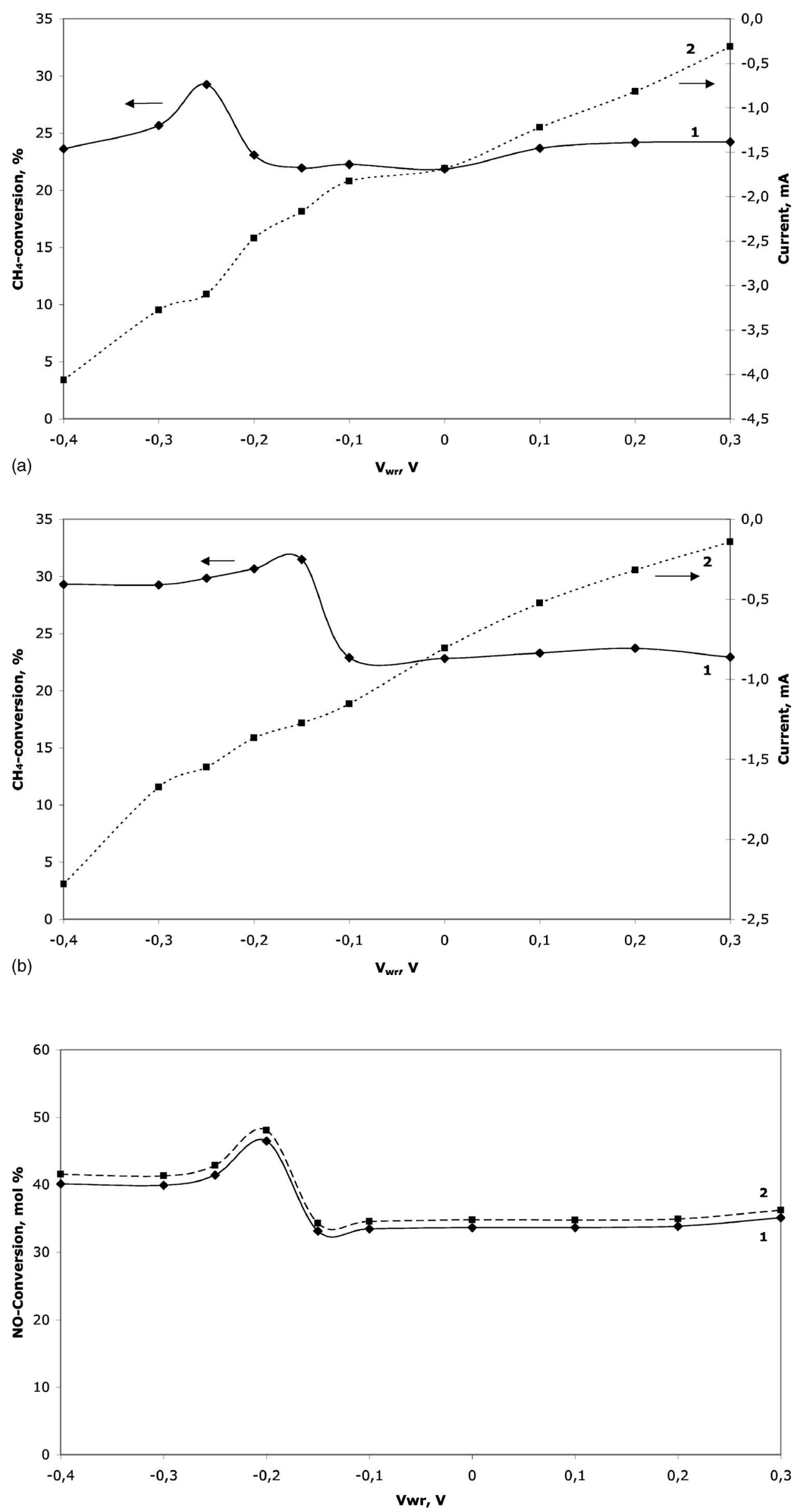

Figure 7. (a) $\mathrm{CH}_{4}$ conversion vs $V_{\mathrm{WR}}$ obtained in the $\left(\mathrm{NO}, \mathrm{CH}_{4}, \mathrm{Ar}\right), \mathrm{Pt} \mid \mathrm{PBI}-$ $\mathrm{H}_{3} \mathrm{PO}_{4} \mid \mathrm{Pt},\left(\mathrm{H}_{2}, \mathrm{Ar}\right)$ fuel cell at $135^{\circ} \mathrm{C}$ and atmospheric pressure (curve 1). Steadystate voltammetric curve obtained in the same conditions (curve 2). This was the 2nd polarization run. (b) $\mathrm{CH}_{4}$ conversion vs $V_{\mathrm{WR}}$ obtained in the $\left(\mathrm{NO}, \mathrm{CH}_{4}, \mathrm{Ar}\right)$, $\mathrm{Pt}\left|\mathrm{PBI}-\mathrm{H}_{3} \mathrm{PO}_{4}\right| \mathrm{Pt},\left(\mathrm{H}_{2}, \mathrm{Ar}\right)$ fuel cell at $165^{\circ} \mathrm{C}$ and atmospheric pressure (curve 1). Steady-state voltammetric curve obtained in the same conditions (curve 2).
Figure 8. NO conversion vs $V_{\mathrm{WR}}$ obtained in the $\left(\mathrm{NO}, \mathrm{CH}_{4}, \mathrm{Ar}\right), \mathrm{Pt}\left|\mathrm{PBI}-\mathrm{H}_{3} \mathrm{PO}_{4}\right| \mathrm{Pt}$, $\left(\mathrm{H}_{2}, \mathrm{Ar}\right)$ fuel cell at $135^{\circ} \mathrm{C}$ and atmospheric pressure (curve 1). This was the 3rd run. NO conversion obtained at the same conditions but with added calculated faradaic part of the net $\mathrm{NO}$ conversion (curve 2). 
The Technical University of Denmark assisted in meeting the publication costs of this article.

\section{References}

1. R. Burch and A. Ramli, Appl. Catal., B, 15, 49 (1998)

2. R. Burch and A. Ramli, Appl. Catal., B, 15, 63 (1998).

3. R. Mariscal, S. Rojas, A. Gómez-Cortés, G. Díaz, R. Pérez, and J. L. G. Fierro, Catal. Today, 75, 385 (2002).

4. I. M. Petrushina, V. A. Bandur, F. Cappeln, and N. J. Bjerrum, J. Electrochem. Soc., 147, 3010 (2000).

5. I. M. Petrushina, V. A. Bandur, F. Cappeln, N. J. Bjerrum, and L. Qingfeng, J. Electrochem. Soc., 149, D143 (2002).

6. I. M. Petrushina, V. A. Bandur, F. Cappeln, N. J. Bjerrum, R. Z. Sørensen, R. H. Refshauge, and L. Qingfeng, J. Electrochem. Soc., 150, D87 (2003).

7. L. Qingfeng, X. Gang, H. A. Hjuller, R. W. Berg, and N. J. Bjerrum, J. Electrochem. Soc., 142, 3250 (1995).

8. Q. Li, R. He, J. O. Jensen, and N. J. Bjerrum, Fuel Cells, 4, 147 (2004).

9. C. Wagner, Adv. Catal., 21, 323 (1970).

10. S. Puncharatnam, R. A. Huggins, and D. M. Mason, J. Electrochem. Soc., 122, 869 (1975).

11. C. G. Vayenas, S. Bebelis and S. Ladas, Nature (London), 343, 625 (1990)

12. C. G. Vayenas, S. Bebelis, C. Pliangos, S. Brosda, and D. Tsiplakides, Electrochemical Activation of Catalysis: Promotion, Electrochemical Promotion, and Metal-Support Interactions, Kluwer Academic/Plenum Publishers, New York, (2001).

13. J. Poppe, S. Völkening, A. Schaak, E. Schütz, J. Janek, and R. Imbihl, Phys. Chem. Chem. Phys., 1, 5241 (1999).

14. V. D. Belyaev, T. I. Politova, and V. A. Sobyanin, Solid State Ionics, 136-137, 721 (2000).

15. D. A. Emery, R. J. C. Luke, P. H. Middleton, and I. S. Metcalfe, J. Electrochem. Soc., 146, 2188 (1999)
16. I. S. Metcalfe, J. Catal., 199, 247 (2001).

17. I. S. Metcalfe, J. Catal., 199, 259 (2001).

18. R. B. Anderson, Experimental Methods in Catalytic Research, Academic Press, New York (1968)

19. R. M. Lambert, A. Palermo, F. J. Williams, and M. S. Tikhov, Solid State Ionics, 136-137, 677 (2000)

20. I. V. Yentekakis, M. Konsolakis, R. M. Lambert, A. Palermo, and M. Tikhov, Solid State Ionics, 136-137, 783 (2000).

21. F. J. Williams, A. Palermo, M. S. Tikhov, and R. M. Lambert, J. Phys. Chem. B, 105, 1381 (2001)

22. I. V. Yentekakis, R. M. Lambert, M. Konsolakis, and V. Kiousis, Appl. Catal., B, 18, 293 (1998)

23. C. Pliangos, C. Raptis, T. Badas, D. Tsiplakides, and C. G. Vayenas, Electrochim. Acta, 46, 331 (2000).

24. C. Pliangos, C. Raptis, T. Badas, D. Tsiplakides, and C. G. Vayenas, Solid State Ionics, 136-137, 767 (2000)

25. G. Fóti, O. Lavanchy, and C. Comminelis, J. Appl. Electrochem., 30, 1223 (2000)

26. S. Kim and G. L. Haller, Solid State Ionics, 136-137, 693 (2000).

27. M. Machida, E. Shono, M. Kimura, and S. Yamauchi, Catal. Commun., 4, 631 (2003).

28. M. Nagaro, T. Yoshii, T. Hibino, M. Sano, and A. Tomita, Electrochem. Solid-State Lett., 9, J1 (2006).

29. L. Qingfeng, X. Gang, H. A. Hjuler, R. W. Berg, and N. J. Bjerrum, J. Electrochem. Soc., 141, 3114 (1994).

30. L. Qingfeng, H. A. Hjuler, and N. J. Bjerrum, Electrochim. Acta, 45, 4219 (2000).

31. R. He, Q. Li, G. Xiao, and N. J. Bjerrum, J. Membr. Sci., 226, 169 (2003).

32. Y. Jiang, I. V. Yentekakis, and C. G. Vayenas, Science, 264, 1563 (1994).

33. M. Stoukides, Catal. Rev. - Sci. Eng., 42, 1 (2000).

34. N. Lapeña-Rey and P. H. Middleton, Appl. Catal., A, 240, 207 (2003).

35. T. Tagawa, K. Kuroyanagi, S. Goto, S. Assabumrungrat, and P. Praserthdam, Chem. Eng. J., 93, 3 (2003).

36. S. Seimanides and M. Stoukides, J. Electrochem. Soc., 133, 1535 (1986) 